\title{
Erratum to: Identifying Community Needs and Resources in a Native Community: A Research Partnership in the Pacific Northwest
}

\author{
Lisa Rey Thomas • Dennis M. Donovan • \\ Robin L. W. Sigo
}

Published online: 29 September 2009

(C) Springer Science + Business Media, LLC 2009

\section{Erratum to: Int J Ment Health Addiction DOI 10.1007/s11469-009-9233-1}

In the above mentioned article, the following information is missing:

The project described was supported by Award Number R24MD001764, "The Healing of the Canoe", from the National Center On Minority Health and Health Disparities. The content is solely the responsibility of the authors and does not necessarily represent the official views of the National Center On Minority Health And Health Disparities or the National Institutes of Health.

The online version of the original article can be found at http://dx.doi.org/10.1007/s11469-009-9233-1.

L. R. Thomas $(\bowtie) \cdot$ D. M. Donovan

University of Washington Alcohol and Drug Abuse Institute, Seattle, WA, USA

e-mail: 1rthomas@u.washington.edu

R. L. W. Sigo

Suquamish Tribe, Suquamish, WA, USA 